\title{
Adult Interdependent Relationships: Alberta-Style Equality for Same-Sex Couples
}

\author{
Craig Stumpf-Allen
}

Craig Stumpf-Allen manages the Edmonton Highlands Constituency Office. He has been a spokesperson for Gay And Lesbian Awareness, and with his husband Mark has been a long-time and outspoken advocate for equality for gay and lesbian individuals and couples.

I n January 2002, the Alberta Government began a consultation on issues in family law. While the original plan was to consider topics such as spousal support, child support, and guardianship, the discussion was broadened to include the controversial issue of how to extend equality to same-sex couples. After numerous court decisions in Alberta and elsewhere in Canada, the government knew they had to change the law to treat same-sex couples on par with their opposite-sex counterparts. The Family Law Reform Project was to solicit opinions on alternative models on how to meet constitutional requirements and assist the government in drafting legislation to be introduced later that spring.

\section{Legal and Legislative History}

Alberta has been struggling with the issue of equality for gay, lesbian, and bisexual Albertans since before the Delwin Vriend decision at the Supreme Court in April 1998. After Vriend, a teacher at a Christian college, was fired because of his sexual orientation, he attempted to file a complaint with the Alberta Human Rights Commission. He was refused on the grounds that sexual orientation was not a protected ground under the Alberta Individual Rights Protection Act (IRPA). After a seven-year legal battle, the Supreme Court ruled unanimously that sexual orientation was analogous to 
other grounds included in section 15 of the Charter, the equality guarantee. The IRPA therefore violated the Charter and accordingly sexual orientation was to be read into the Alberta statute. Members of the Alberta government considered using the Notwithstanding Clause of the Constitution to avoid complying with the Court's decision. In the end, however, the government chose to do nothing. They did not invoke the Notwithstanding Clause - nor did they amend the IRPA in the Legislature, a failure some considered an important statement about the government's lack of commitment to equality.

The issue of how to treat same-sex couples came to the fore on the national stage as a result of the $\mathrm{M}$ v. $\mathrm{H}$ ruling by the Supreme Court in May 1999. After the break up of a lesbian relationship, one partner sued the other for support. $M$ argued that by failing to include her relationship in its spousal support provisions, the Family Law Act of Ontario violated section 15 of the Charter, because same-sex relationships like hers were not much, if any, different than oppositesex relationships. The Supreme Court agreed, and the government of Ontario was forced to change its laws to recognize the equality of same-sex relationships.

Following this decision, several provinces (including Quebec, Ontario, BC, Saskatchewan, Manitoba, Nova Scotia, and Newfoundland) and the federal government introduced legislation to create equality for same-sex couples. These laws have in common that they extend marriage-like rights only to couples in conjugal relationships, and they apply equally to common law couples of the same or opposite genders. Most define a time requirement of one to two years that couples must cohabitate before they are eligible to receive benefits. Nova Scotia was alone in creating a domestic partnership registry. This allows couples to bypass the waiting period to qualify for equality.

\section{Alberta's Family Law Reform Project}

Unlike other jurisdictions, Alberta made no legislative changes in response to M v. H. However, in April 2001 the Court of Queen's Bench ruled that the Intestate Succession Act violated the Charter of Rights and Freedoms by excluding same-sex couples. The Court case revolved around the sudden death of Larry Sand, a man without a will. According to the Intestate Succession Act, when there is a 
spouse and children, an estate is split among the spouse and children. However, because the deceased was in a same-sex relationship and the law did not recognize his partner, Brent Johnson, as a spouse, Sand's children were his sole heirs under the law at the time. Johnson challenged the law and was successful. The government was given nine months to change the law (until January 2, 2002).

When the Johnson v. Sand decision was made, the government had already begun plans for a review of family law. This review was to cover several areas, including spousal support, child support, guardianship, custody and access, and court jurisdiction and powers. There was some talk of expanding the review to consider how to deal with the issue of extending equality to same-sex couples. However, as late as July 2001, Justice Ministry employees were unsure whether the issue of same-sex couples would be included in the consultations (Booth). The Courts had already indicated that same-sex couples must be treated equally.

By October 2001 the government had determined that the Family Law Reform Project would definitely be broadened (Steed). While the Courts had made the need for equality clear, Alberta was considering alternative models of how to achieve this goal. The hope was to have public consultations started by the fall of 2001, as the deadline for the correction of the Intestate Succession Act was January 2, 2002. However, in November 2001, the government applied to the Court to delay the deadline for implementation of changes to the Intestate Succession Act until July 2, 2002. The government indicated it was delaying due to a need for more time to conduct the Family Law Review. They wanted to change the law as part of the wider review. The Court granted an extension of only three months, to April 2, 2002. The decision was that if the government needed more time based on their consultation process and could give evidence of that need, they could reapply for a further extension.

The Alberta government did not formally launch the Family Law Reform Project until January 10, 2002, a full nine months after the Court's decision on Intestate Succession and nearly three years after the Supreme Court's decision in M v. H had indicated the direction in which Canadian governments must move. Alberta proposed something no other province had tried, extending marriage-like benefits to people living in platonic relationships. Immediately, critics 
identified risks to this approach (Simons). There is a different quality of relationship between two people in a conjugal relationship and those living platonically. Extending the law in this way was seen as imposing responsibilities on those who may not desire them and could result in a flurry of lawsuits as people test the boundaries of the new legislation. As well, this approach was seen by many gay activists as trying to minimize the reality of same-sex relationships by hiding them in a haze of "interdependent relationships." Finally, some critics identified costs as a concern, as pension and workers' compensation benefits could be paid out to persons other than spouses.

The Project included the opportunity for members of the public to complete questionnaires on paper or on the Web, a public opinion poll, focus groups with randomly selected Albertans, single parents, and adolescents, as well as technical focus groups for legal and nonlegal professionals with special interests in family law (Chance). According to the government, this final group included some gay and lesbian individuals and organizations.

Later that month, the Alberta government, faced with a lawsuit by an anonymous employee in a same-sex relationship, extended pension benefits to same-sex partners of its top civil servants. This decision was made in the face of a Court case from October 2001 that was about to be released. The government amended the regulation to replace "spouse" with "pension partner." The term "pension partner" would only apply to persons in conjugal relationships. At the time of the decision, the Finance Department indicated it would be looking at other pension plans once the Family Law project was complete. The preference in this case would have been to wait, but the Court challenge forced the government to speed up the process.

A month after the extended deadline to amend the Intestate Succession Act, the government passed Bill 29. This Bill altered the act to include a definition of "Adult Interdependent Partner," a person in a conjugal relationship with the deceased.

\section{Bill 30: The Adult Interdependent Relationships Act}

The provincial government introduced Bill 30, the Adult Interdependent Relationships Act, at the same time as Bill 29. Bill 30 differs in several ways from the omnibus bills passed by other 
jurisdictions. First, the qualifying time is significantly longer: three years. However, like Nova Scotia, Alberta chose to allow couples to skip that process by signing a written adult interdependent partnership agreement. Second, Alberta was alone in choosing to extend marriage-like rights and responsibilities to people living in platonic relationships. The definition of Adult Interdependent Partners includes several variables, some or all of which may be present in any relationship. Conjugality is one of those variables, but is not a necessary condition to qualify.

The determination of whether two people are "adult interdependent partners" is based on several variables:

- whether it is a conjugal relationship;

- the degree of exclusivity;

- the conduct and habits of the persons regarding household activities and living arrangements;

- the degree to which the persons present themselves as an economic and domestic unit;

- the degree to which legal obligations are formalized;

- the extent to which contributions have been made to each other's well-being;

- the degree of financial interdependence;

- the care and support of children;

- and the ownership, use, and acquisition of property.

As well, couples must have lived together for at least three years, have a child together, or have signed an Adult Interdependent Partner Agreement.

While at least sixty laws have been identified as including a reference to (opposite-sex) spouses and thus as discriminatory to same-sex couples, only nine of those laws are altered by this Act. These fall into three general areas:

- laws dealing with the death of a person, such as the Intestate Succession Act (which would be amended for a second time to be in line with the new definition);

- laws for dealing with the breakup of a relationship, such as the Matrimonial Property Act;

- and the Change of Name Act, which allows spouses to take one another's surname.

The definition of Adult Interdependent Partner is based on the model introduced in the Family Law Reform Project. However, the 
final report on this project has not yet been released. It is not clear whether the majority of respondents supported the use of this model or what arguments were made for and against it.

\section{Analysis}

Because the Adult Interdependent Relationships Act deals with two very different types of relationships, conjugal and nonconjugal, the benefits and drawbacks must be considered for each separately.

For same-sex couples, this Act does not provide full equality. As mentioned above, the Act amends only nine laws, out of approximately sixty that refer to spouses. Some laws of significance that are not covered include:

- the Alberta Evidence Act, which prevents spouses from being compelled to disclose any communication made to one another during the marriage;

- the Employment Pension Plans Act, which allows pension benefits to be payable to spouses and commonlaw spouses, including after the death of the contributing spouse;

- the Health Insurance Premiums Act, which allows opposite-sex couples to receive family coverage and thus be covered by the partner's work benefits;

- the Human Tissue Gift Act, which allows a spouse to donate the organs of a deceased person;

- and the Widows' Pension Act, which provides a pension to low income widows and widowers, between ages 55 and 64 .

The definition of who can be considered Adult Interdependent Partners also does not provide full equality for same-sex couples. They must live together; if they cannot, due to work or other considerations, same-sex couples cannot qualify. As well, the variables that define adult interdependent partners include the consideration of exclusivity. This is not a requirement for opposite-sex couples and would disqualify some same-sex couples. Another variable is the degree to which the couple present themselves to the community as an economic or domestic unit. If the couple cannot be public for whatever reason, they could lose their rights under this Act.

As well, Julie Lloyd, human rights lecturer and lawyer for Brent Johnson and the senior civil servant in the pension case, compares 
the creation of a new status for same-sex couples to separate water fountains for whites and nonwhites. "The same messages of 'otherness' and inferiority are conveyed, and the same type of discriminatory attitudes are condoned and perpetuated" (Lloyd 3). This argument is supported by the Act itself. While the Act states that "it is recognized in Alberta as a fundamental principle that marriage is a union between a man and a woman to the exclusion of all others," it makes no mention of same-sex relationships (Adult Interdependent Relationships Act 1). As Brian Mason, a New Democrat MLA in Edmonton, said in the Legislature, the Bill "is an attempt to pretend that gays and lesbians don't exist in this province" (Alberta Hansard 1288).

For people in platonic relationships, who have signed a lease together, bought a computer together, or share living expenses, this Act could produce unintended and unanticipated results. After the death of one, the other could make a case for primary access to the estate; following the end of cohabitation, a case could be made for support. In most cases, two people living together in a platonic relationship do not expect to have obligations to one another that would extend past the end of the relationship. This Act could result in some nasty surprises. Furthermore, if the Act is amended to include laws that are so far excluded, the possibility of surprise obligations becomes even greater. For instance, the income of a roommate could prevent a single parent from receiving day care subsidies that allow her to work.

There is also the question of why the government is expanding the rights and responsibilities of marriage to platonic relationships. Was there a demand for this? Without the final report of the Family Law Reform Project, this question cannot be answered. However, it does seem clear that more work must be done on this aspect of the law to protect platonic partners from unintended and undesired obligations.

Finally, in late May 2002, following the introduction of Bills 29 and 30, the province changed regulations for five more pension plans. Again, this was in response to a Court challenge. And again, the definition for pension partner included only couples in conjugal relationships. Therefore, the degree to which the government is sincere about wanting to extend marriage-like rights and responsibilities to people in platonic relationships is unclear. 


\section{What Next?}

As Mason said in the Legislature, "the strategy of this government regarding the obligations to gays and lesbians in Alberta has been to delay, delay, and further delay again." He continues: "Let's be clear. While the government delays, real people lose out economically, socially, and emotionally" (Alberta Hansard 1288).

Based on a long experience of fighting the Alberta government for equality, gay and lesbian individuals, couples, and families in Alberta know they cannot count on the government to act on any issue related to their rights unless forced to do so. Couples to whom nonamended laws apply will have to continue to seek justice through the Human Rights Commission and the Courts. In fact, following a successful complaint to the Human Rights Commission on Health Insurance Premiums, and the government lack of adherence to the Commission's order, the Commission will be taking the government to Court on behalf of the complainants in the fall of 2002. Similarly, a decision is pending from the Human Rights Commission on employment benefits for same-sex partners of government employees.

The Legislature will reconvene in November 2002 and debate on Bill 30 will proceed at that time. It may be that the government will introduce amendments to the Bill to extend it to some or all of the fifty laws that are so far excluded. Unfortunately, the failure of the Act to treat same-sex couples on par with their opposite-sex counterparts will mean that even if the government amends all laws, the legal battles will not end. And for Albertans living in platonic relationships, those battles may just be beginning.

\section{Addendum}

Since this article was written, Bill 30 has been passed in an amended form. While many more Acts have been amended to include adult interdependent partners, the definition remains the same, as do many of the concerns raised in this article. Most sections of the Adult Interdependent Relationships Act will be proclaimed June 1, 2003.

The government continues to fight human rights complaints by its staff for same-sex spousal benefits. 
202 / Stumpf-Allen

\section{Acknowledgments}

Thanks to Kristy Harcourt, Julie Lloyd, John Plews, Chris Samuel, and Mark Stumpf-Allen, for their insights and comments on the Family Law Reform Project, Bill 30, and this article.

\section{Works Cited}

Adult Interdependent Relationships Act. 2002. Alberta's Queen's Printer.

Alberta Hansard. 35 (2002): 1286-1289.

Booth, John [Alberta Justice and Attorney General, Legal Services].

Personal interview. 24 July 2001.

Chance, Jason [Alberta Justice and Attorney General, Communications]. Personal interview. 9 Sept. 2002.

Lloyd, Julie. "Equality for All? The Case for Same Sex Marriage in Canadian Law." Canons of Construction 32.3 (2001): 3.

Simons, Paula. "Proposed expansion of spousal rights will open

Pandora's Box: Advent of adult interdependent partners will see flood of legal tests." Edmonton Journal 26 Nov. 2002: B1.

Steed, Nolan [Alberta Justice and Attorney General, Family Law Reform Project]. Personal interview. 5 Oct. 2001. 